\title{
Innovative Policy for Governance Development : Analysis of Indonesian Civilian State Apparatus Policy
}

\author{
Marlan Hutahaean \\ Department of Public Administration, Faculty of Social and Political Sciences \\ Nommensen HKBP University \\ Medan, North Sumatra - Indonesia \\ marlanhutahaean1965@gmail.com
}

\begin{abstract}
This paper aims at analysis innovative policy which is made in order to reform the civilian state apparatus. Focus of the study is the Law No. 5 of 2014 about Civilian State Apparatus or Indonesian Civil Service, especially Civil Servant. The choice of this policy is due to the civilian state apparatus which is central to the process of governance development, particularly the public service. Although Law No. 43 of 1999 has been set on the prohibition of civil servants to be members of political parties, but the ban of relationship between them is not clearly regulated. Using the methods of policy analysis and secondary data, the study found that: 1. Law no. 5 of 2014 has emphasized the importance of performance as a parameter in measuring the success of CSA and the organization. 2. This policy has been trying to limiting relations between the bureaucrats and political officials. 3 . This policy also has eliminated the dichotomy of central government - local apparatus through the elimination of the term of local apparatus. The bureaucrat is the CSA which is obedient to the Law and work for the public interest. 4. This policy was the establishment of the CSA Commission which is independent to select the officials who will occupy the echelons I. Based on the findings obtained, this study recommend: first, there needs to be commitment from the civilian state apparatus to implement this policy. Second, the need for political support from Parliament through the budget and control functions. Third, the need for giving authority to the Civilian State Apparatus Commission not only for selecting officials but also for recruitting the civilian state apparatus candidates.
\end{abstract}

Keywords : innovative policy, civil state apparatus, sustainable deveopment, public service.

\section{Introduction}

This paper aims at analysis the innovative policies which is made for bureaucratic reform or civilian state apparatus. The policy that is the focus of the study is Law no. 5 Year 2014 on Civilian State Apparatus (CSA) or Indonesian Civil Service, especially Civil Servant (CS). The choice of this policy because CSA is central to the process of governance of development, particularly in public services. It is generally known most programs or policies are formulated and implemented by the CSA. Even if private, NGOs or civil society are involved, their role is very limited.

The concept of innovation has attracted considerable attention over the past several decades, spawning a voluminous literature and widespread belief in the inherent value of innovation (Sears and Baba, 2011). Innovation policies can be classified as demand-side 
oriented or supply-side oriented (Edquist and Hommen, 1999). It means that innovation depends on demands for urgent circumstances or because it is made to anticipate future events. When associated with the needs of the effectiveness of implementation of an organization, Elkin (1983) stated that three separate impulses to innovation can be observed operating in organizations. Organizations consider innovations: (1) because some number of organizational members finds it personally advantageous to support an innovation and attempts to induced a sufficient number of their colleagues to go along; (2) because organizational members are subject to influence by an outside actor (s); (3) or because members believe that it will solve an organizational problem to alter the manner in which the organization conducts its business.

In the policy contex, Down (1976) is defines that policy innovations as:

..... policies new to the political units adopting them no matter how long they have been around or how many comparable units may have adopted them. While no clear, unambiguous criteria exists for distinguishing policy innovations form any minor modification in currents practices, the label is normally applied only to politics that represent significant, unprecedented, and qualitative departures from past policies. (p. $\mathrm{xV}$ )

Down's view shows that policy innovation is a policy option that contains new breakthroughs and that sets them apart from previous policies. Similarly, Law no. 5 of 2014 on the CSA, is a policy that contains a new breakthrough in terms of civil service management in Indonesia. This policy differs substantially from previous policies, namely Law no. 8 of 1974 on the Indonesian Personnel Management (IPM) as amended by Law no. 43 of 1999.

Up to now the policies or laws governing the CSA, especially Civil Servant, as mentioned above, do not strictly regulate the obligations of Civil Servant in generating performance, in particular organizational performance. The systems built so far in assessing the performance of bureaucrats greatly influence their behavior. Performance measurement of employees so far still refers to the assessment system of what is called the List of Personnel Performance Appraisals (DP3), which is determined through the Circular Letter of the Head of the State Personnel Administration Agency (BAKN) No. 02 / SE / 1980, February 11, 1980. DP3 is related to loyalty, achievement, obedience, responsibility, honesty, cooperation, initiative, and leadership. DP3 set by the head of BAKN, shows that the performance of bureaucrats is measured from whether they are subject to the orders of their superiors or not. As a result, bureaucrats prefer services to their superiors rather than to the public (citizens).

The low assessment of individual performances, programs and institutions, makes every bureaucrat workless professionally. Moreover punishment in the form of dismissal if they are not able to give good performance, not regulated explicitly in personnel regulations. As a result, the bureaucrats, as mentioned above, prefer to provide service to the leader rather than to the public.

In addition, Law no. 43 of 1999 does not strictly regulate the prohibition of Civil Servant to become members of political parties. This makes the bureaucrats often stuck in a circle of politicization. Political parties often take advantage of the strategic position of bureaucrats to realize their desires. Law no. 5 of 2014 is explicitly regulates the prohibition of Civil Servant become members and administrators of political parties. However, despite Law no. 5 of 2014 has governed the prohibition of Civil Servant to become members and 
administrators of political parties, but a clear prohibition of relations between them is not strictly regulated. When local elections take place, it is still difficult for the regional apparatus to be neutral. On the contrary, the candidate for regional head also tried to attract the regional apparatus to become a disguised success team. The question is what innovations are contained in Law no. 5 of 2014? What are the implications of this innovative policy on development governance, particularly public services?

\section{Method}

The method used in analyzing data is public policy analysis method. This method will analyze and describe the root of cause of the policy up to the possibility of implementation. The data used for analysis are secondary data derived from books, previous research results, journals, online media, commentaries of relevant experts, bureaucrats, party elites, and websites.

\section{Results and discussions}

Urgency of change of Law no. 8 of 1974 as amended by Law no. 43 of 1999 on the IPM is due to this Law establishing the application of career-based employment system that emphasizes the rights, obligations, duties, and procedures of civil servant management individually in order to build the State Apparatus Human Resources with centralized management. This paradigm requires the change of resource management from an old perspective of personnel management that emphasizes the rights and obligations of individual employees to a new perspective that emphasizes on strategic human resources management in order to always be available, that of resources of the superior state civil apparatus in harmony with the dynamics of the change of civil state apparatus mission.

Answering the need for such change, it is desperately needed an innovative policy, a policy that is fundamentally different from the previous policy. Law no. 5 of 2014 on the CSA enacted on January 15, 2014, ultimately responding to be the intended desire. This law is structured on the basis of the ideas widely used by developed countries based on the paradigm of staffing management that to support the development of democratic and decentralized governance, as well as the increasingly open social market economy, it is necessary to develop the CSA which has the strength and higher ability and increasingly able to carry out the achievement of government's political goals and programs.

Law No. 5 of 2014 is an innovative policy in regulating the CSA. At least this law has four things that are different from the existing law, namely:

1. Law no. 5 of 2014 has underscored the importance of performance as a parameter in measuring the success of CSA and the organization.

2. This policy has tried to keep the distance between bureaucrats and political officials.

3. This policy has also eliminated the dichotomy of central-local officials through the abolition of the term of the local apparatus. The bureaucrat apparatus is the state civil CSP that is subject to the Act and works for the public good.

4. This policy is the establishment of an independent Civilian State Apparatus Commission (CSAC) with the task of selecting officials who will occupy the echelon I. 


\section{A. Performance as a Parameter Measuring Individual and Organizational Success}

The performance can be seen from 3 (three) aspects, namely individual performance, program performance and organizational performance. Individual performance is emphasized at the level of achievement of each employee over the workload in accordance with the main task and function. Employees who provide output according to their main tasks and functions are considered to perform well. Program performance is defined as whether the entire program developed, both in the short, medium and long term can be achieved in accordance with the time and capabilities of the available budget. Finally, organizational performance is whether the basic tasks and functions of employees who worked in accordance with the program in order to achieve the vision, mission, goals and objectives of the organization. That means these three types of performance are one interconnected system.

Related to this performance, Law no. 8 of 1974 focuses more on individual performance. Individual performance serves as a parameter in appointing an employee to be promoted to a particular position. Article 19 expressly states that appointment in office is based on work performance, work discipline, loyalty, dedication, experience, trustworthiness, and other objective requirements. The objective requirement is set forth in the Employee Performance Appraisal List which is actually vulnerable to subjective judgment. Because the assessment of an employee's performance is very dependent on the assessment of leadership. Dwiyanto (2015) expressly states:

The basis of performance appraisal that relies solely on superior assessments without clear indicators for measuring the various performance aspects used in the DP3 makes a performance appraisal entirely a subject of leadership subjectivity. As a result, the leadership in filling the DP3 tends to simply meet the need to comply with the rules instead of making it an instrument to measure the performance of its subordinates. (p. 145)

Unlike the previous policy, Law no. 5 of 2014 can be used as a legal umbrella to force changes in the behavior of Civil Servants. While it still has some disadvantages, this policy has been regulated in addition to individual performance, also regulates organizational performance. This is stipulated in article 76 paragraph (1) stating that performance appraisal of civil servants is based on performance planning at individual level and unit level or organization, taking into account the targets, achievements, results, and benefits achieved, and the behavior of civil servants. Assessment of the performance of Civil Servants is done objectively, measurable, accountable, participatory, and transparent. Furthermore, the results of the Civil Servant's performance appraisal are used to ensure objectivity in its development, and also as a requirement in appointment and promotion, the provision of benefits and sanctions, mutations, and promotions, and to follow education and training. In contrast, for Civil Servants whose performance appraisal does not achieve performance targets shall be liable to administrative sanctions up to termination in accordance with the provisions of legislation. Thus, it is clear that this policy has implemented a reward and punishment system.

In addition, this policy strictly regulates the duty of Civil Servants, namely, (a) implementing public policies created by civil service officers in accordance with the provisions of legislation; (b) provide professional and qualified public servants, and (c) strengthen the unity and unity of the Unitary State of the Republic of Indonesia. 
Although Law no. 5 of 2014 has given hope for improvement of behavior of Civil Servants, in terms of employee performance appraisal, it still has weaknesses. This Act has indeed changed the way employee appraisals become performance-based. However, the performance of Civil Servants is only measured at individual and organizational levels based on performance plans, target achievement and employee behavior. While the performance of the program has not been a concern. Though the performance of this program will show to every employee whether able to formulate, implement in order to achieve the vision, mission, goals and goals of the organization.

\section{B. Neutrality of Civilian State Apparatus}

During the New Order period, Indonesia used the bureaucratic-polity model. The bureacratic-polity model is a form of political system in which the power and political participation in making decisions are limited entirely to state authorities, especially military officers and high-ranking bureaucrats (Jackson, 1978). Furthermore Jakson (1978) mentions that: "bureaucratic-polity that is, a political system in which power and participation in the state of affairs, especially the officer of the corps and the highest levels of the bureaucracy, including especially the highly trained specialists known as the technocrats."(p. 3)

More specifically, Crouch (1980) notes that bureaucratic-polity in Indonesia contains three main features: first, the dominant political institution is bureaucracy. Secondly, other political institutions such as parliaments, political parties, and interest groups are in a weak state, unable to balance or control the bureaucratic power. Third, the mass outside the bureaucracy is politically and economically passive, which is partly the weakness of political parties in mutually reinforcing bureaucracy.

During this time civil servants became part of a political party. At all levels of government, bureaucratic officials automatically become the members of the ruling political party at that time the Golkar. Moreover, in the management of this political party comes from three main pillars, namely ABRI, Bureaucracy, and Golkar (ABG). Thus, every civil servant automatically also becomes a party official and / or member of a political party. That means, the neutrality of civil servants during the implementation of Law no. 8 of 1974 is absolutely absence.

The neutrality of the civil servant is indicated by the permission of an employee to become a state official without removing his employment status. A person appointed as a state official, such as the president, vice president, chairperson, vice chairperson and member of the People's Consultative Assembly, chairman, vice chairman and member of the People's Legislative Assembly, governor and deputy governor, regent / mayor and deputy regent / deputy mayor, will not lose his status as a civil servant. In fact, the entire position is a political position, which should be avoided, or at least dismissed as a civil servant after being sworn in as state official.

Unlike the previous policy, Law no. 5 of 2014 expressly regulates the neutrality of the CSA. Those who elect and be appointed as state officials, especially for the positions mentioned above, shall declare a written resignation in writing as a Civil Servant since registering as a candidate. This rule certainly implies the professionalism of the CSA. That is why it is mentioned in Law no. 5 of 2014 that the CSA as a profession for Civil Servants and Government Employees with Work Agreement (PPPK) working in government agencies. 


\section{The End of the Dicotomy of Central - Regional Officers}

Law no. 8 of 1974 article 2 paragraph (2) explicitly states that Civil Servants are divided into Civil Servants of Central and Local Civil Servants and other Civil Servants. This dichotomy clearly indicates that there is a degree of civil servant status. The effect of this dichotomy is the emergence of "superior" and "inferior" employees. Central employees are those who are "superior" and when performing tasks to the region, as if the most correct and omniscient. In contrast, local officials are those who are "inferior" when meeting central employees. Self-esteem seems to disappear when taking care of a job in the central government.

Evidence of the dichotomy of the central employee and the local employee is the difference between the Personnel Number Code (NIP) between the two. The central employee is shown with the same number in front of him, namely the number 01 and so on. Whereas the regional officers of the initial two numbers of the Personnel Number Code are dependent on the province area. This Personnel Number Code can also be used as "weapon" especially by central employee especially to increase confidence. In contrast with the local officials.

In Law no. 5 Year 2014, the dichotomy of central employees and local officials has been removed. Article 6 states that CSA employees consist of Civil Servants and Government Employees with Work Agreement. That means there is only one for the Civil Servant designation and they are called the CSA. In addition to Civil Servants, there are also Government Personnel with Work Agreement.

The equation of designation for Civil Servants across Indonesia is not only in order to eliminate the dichotomy, but to change the paradigm of thinking that they have the same task, regardless of the place of work, namely the CSA whose primary task is to provide public services. The task of providing public services, also affirms that they are public servants. As a public servant, of course, be pro-active is the needs of the community without making a difference. In addition, the superior and inferior attitudes that have been attached, will disappear by itself.

\section{Civilian State Apparatus Commission}

Law no. 43 of 1999 as amendment to Law no. 8 of 1974 had previously set about the State Personnel Commission. The Commission consists of the chairman, secretary and 3 nonpermanent members appointed by the president. The problem is, the chairman and secretary are ex officio held by the head and deputy head of the State Personnel Board. That means the Commission is not an independent institution.

Law no. 5 of 2014 is significantly different from the previous Law relating to this Commission. This law regulates the establishment of a Civilian State Apparatus Commission (KASN) which is an independent non-structural institution free from political intervention. That means, KASN is an independent institution. The 7 (seven) members of the KASN are appointed by the president after being tested through a written test and fit and proper test. This open-bidding recruitment provides an opportunity for all members of the community eligible to register.

KASN is responsible for creating professional and performing CSA employees, providing services fairly and neutral, as well as becoming a glue and a unifying nation. KASN is given the authority to monitor and evaluate the implementation of policies and ASN 
Management to ensure the realization of Merit System as well as supervision on the application of CSA principles and code of ethics and code of behavior. In addition to the authority, KASN has the function of overseeing the implementation of basic norms, codes of ethics and code of CSA behavior, as well as the implementation of Merit System in CSA policies and Management in Government Agencies.

Related to its function, KASN is directly involved in the filling of high leadership positions, both at the national level, and in the province. There are at least 3 (three) leadership positions, namely the top leadership positions, madya, and pratama. The main and high-level leadership positions are in the ministries, the secretariats of state institutions, non-structural institutions, and local authorities are conducted openly and competitively among civil servants with due regard to the requirements of competence, qualifications, rank, education and training, job track record and integrity and other requirements which is required in accordance with the provisions of legislation. Whereas the position of Primary Leaders is conducted openly and competitively at national or inter-regency / city level in 1 (one) province.

Furthermore, what are the implications of this innovative policy on development governance, particularly public services? This innovative policy after running for more than 3 (three) years, has implications for the governance of public services. This can be seen from the rating of Government Effectiveness Index (IEP) of Indonesia, which is a measure of the ability of bureaucratic apparatus or Civil Servants in carrying out their duties and functions. Effendi (2018), states that the rise of the Government Effectiveness Index of 23 levels - from rank 121 to rank 98 - occurred because the score of IEP Indonesia rose from 46 in 2016 to 53.37 in 2017 , a fairly high increase of 7.37 due to the level of public confidence that large on government, and due to improved public services. If the high growth momentum can be maintained for 4 years in a row, in 2022 ASN Indonesia will reach the state apparatus of developed countries with the score of IEP 82.75 achieved by BRIC countries and ASEAN developed countries.

\section{Conclusion}

Law no. 5 of 2014 however has given a new nuance in management CSA. As a public servant, the demand for the provision of quality services becomes a necessity. The previously practiced behavior that the newly served first serves, has to be removed. This is related to performance appraisal that prioritizes professionalism and employee performance in carrying out its main duties and functions.

Nevertheless, this Law still needs to get support and improvement to create strategic human resources management in order to always provide the resources of civil apparatus of superior countries in line with the dynamics of change of mission of CSA. Firstly, there needs to be a high level of commitment from state civil servants, especially Civil Servants to implement this policy. Secondly, the need for political support from parliament through budgetary and supervisory functions. The budget function relates to budget approval for employees in the context of awarding rewards. While the supervisory function is concerned with monitoring the performance of employees, programs and organizations through ministers, heads of non-ministerial government agencies, and regional heads. Thirdly, the need to authorize the KASN to perform recruitment of candidates for the CSA and not only to provide recommendations on the selection of high leadership positions that have been done by certain 
agencies. The KASN is centralized in recruiting and establishing Civil Servants who pass the selection.

\section{Acknowledgment}

The Author would like to thank to the Public Administration Department, Faculty of Social and Political Sciences, HKBP Nommensen University that has funded this research.

\section{References}

Crouch, Harold. (1980). The New Order: The Prospect for Political Stability. In Mackie (ed), Indonesia: The Making of A Nation (pp. 657-667). Canberra: The Australian University.

Down, Jr., G.W. (1976). Bureaucracy, Innovation, and Public Policy. Massachusetts: Lexington Books.

Dwiyanto, Agus. (2015). Public Administration: Decentralization, Institutionalization, and Civilian State Apparatus. Yogyakarta: Gadjah Mada University Press.

Edquist, Charles and Hommen, Leif. (1999). Systems of Innovation: Theory and Policy for the Demand Side. Technology in Society, 21, 63-79.

Effendi, Sofian. (2018, January 4). Acceleration of Bureaucracy Reform to Realize Indonesia 2024 and Vision 2045. Paper. Retrieved from http://www.kasn.go.id/details/item/202

Elkin, S.L. (1983). Towards a Contextual Theory of Innovation. Political Sciences, 15, 367387.

Jackson, K.D. (1978). Bureaucratic Politiy: A Theoretical Framework for the Analysis Power and Communications in Indonesia. In Jackson and Pye (eds), Political Power and Communications in Indonesia (pp. 3-22). Berkeley: University of California Press.

Law No. 8 of 1974 on Indonesian Personnel Subjects

Law No. 43 of 1999 on Amandment of Law Number 8 Year of 1974 on Indonesian Personnel Subjects

Law No. 5 of 2014 on Civilian State Apparatus

Schwab, Klaus (ed). (2017). The Global Competitiveness Report 2017-2018. Geneva: World Economic Forum.

Sears, G.J., and Baba, V.V. (2011). Toward a Multistage, Multilevel Theory of Innovation. Canadian Journal of Administrative Sciences, 28, 357-372. 